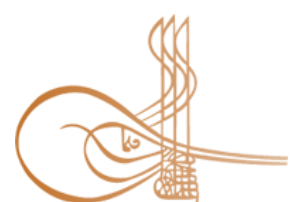

www.turkishstudies.net/economy
Turkish Studies - Economics, Finance, Politics

eISSN: $2667-5625$

Research Article / Araștırma Makalesi

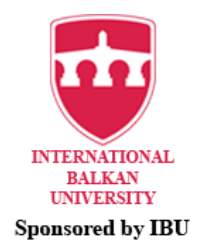

Sponsored by IBU

\title{
Lojistik Alanındaki Lisansüstü Tez Çalışmalarının Sosyal Ăg Analizi ile İncelenmesi
}

Investigation of Postgraduate Thesis Studies in the Field of Logistics with Social Network Analysis

\author{
Erdoğan Çavdar
}

\begin{abstract}
The purpose of this study is to create a map of the changes in the logistics field in terms of postgraduate theses. In accordance with the purpose of the study, the tags related to master's and doctoral theses published between 1990-2018 in the field of logistics were compiled and subjected to social network analysis. In the field information section of the National Thesis Center database, the implications of all the studies with the term "logistics" have been compiled, and a total of 896 postgraduate theses have been reached, 167 of which are PhDs and 729 of them are masters. After publications without publishing permission and studies without keyword information were removed from these, 622 studies were included in the study. In the analysis made on the specified keywords in the studies, the most important concepts were determined as supply chain management, outsourcing, logistics center and reverse logistics. In addition to these concepts, it was determined that the keywords marketing and third party logistics were studied for the first time between 20112014. It was found that between 2015 and 2018, studies on logistics turned into interdisciplinary studies. In this period, it was determined that the concepts of sustainability, customer satisfaction and e-commerce were included in the studies in the field of logistics. Green supply chain management has also started to work for the first time in this period. The findings obtained give information about the course of the studies in the field of logistics. According to the results of the research, the researchers have made suggestions about the need to work on current issues such as logistics innovation, green logistics, city logistics, humanitarian logistics, which are important in the field of logistics.
\end{abstract}

Structured Abstract: Advances in technology and economy have allowed companies to access a wider network of markets and suppliers. With the growth of trade, companies have paid increasingly more attention to logistics management, which plays a key role in business success.

Logistics management is basically the control of the movement of goods and services from origin to destination. However, it is much more than that and includes freight and inventory management, material handling, and order fulfillment.

As a result of changes in management mentality, logistics has moved beyond shipping and become integrated with procurement, demand forecasting, inventory planning and forecasting, ordering process, storage, packaging, loading, transportation, customer service, and recycling (Aslan, Taş̧̧ \& Yıldız, 2018, p. 344).

\footnotetext{
* Dr. Öğr. Üyesi, Kastamonu Üniversitesi, İktisadi ve İdari Bilimler Fakültesi, İșletme Bölümü Asst. Prof., Kastamonu University, Faculty of Economics and Administrative Sciences, Business Administration ORCID 0000-0002-1522-8775

ecavdar@kastamonu.edu.tr
}

Cite as/ Atıf: Çavdar, E. (2020). Lojistik alanındaki lisansüstü tez çalışmalarının sosyal ağ analizi ile incelenmesi. Turkish Studies - Economy, 15(3), 1267-1284. https://dx.doi.org/10.47644/TurkishStudies.42248

Received/Geliş: 24 March/Mart 2020

Accepted/Kabul: 20 September/Eylül 2020

Copyright $(C)$ INTAC LTD, Turkey
Checked by plagiarism software

Published/Yayın: 25 September/Eylül 2020

CC BY-NC 4.0 
Successful logistics management ensures customer satisfaction, follow-up and manageability of activities, low costs, and auditability. The significance of logistics activities for companies has drawn researchers' attention to the phenomenon.

Academic theses in a field of study give us some clues about paradigms in that field of study. Determining those paradigms both contributes to the literature and paves the way for future studies. The aim of this study was to map the changes in terms of graduate theses on logistics.

Surveys, and web-based and archive studies can be conducted to collect data for network research (Ağcasulu, 2018: 1918). In accordance with its objective, this study complied the 1990-2018 master's and PhD theses on logistics at the National Thesis Center and analyzed them using social network analysis.

A social network is a structure of nodes (individuals or organizations) that connects them with each other based on the relationships and interactions between them. Social network analysis is used to scientifically analyze the relationships and interactions between the elements in a social network and to obtain meaningful results. Social network analysis software programs can be used to analyze and visualize numerous complex data (Tekdal, Baz \& Saygıner, 2017)

Network analysis is based on graph theory. A well-structured graph says much more than words. In a social network analysis, a network map arising from actors and relationships is referred to as a social map. Sociograms indicate relationships between actors, help with comparison, guide numerical analysis and point out the general data structure. A sociogram uses an international language and addresses a topic as a whole, and thus, saves time. (Ağcasulu, 2018: 1919-1920)

Network analysis consists of three levels of analysis; dyad, node, and network. The dyadic level analysis refers to the analysis of the relationship between two actors. The node level analysis focuses on the number of relationships between actors. The network level analysis takes all nodes and dyads in a network into account. Therefore, the effect of well-connected networks on the spread of ideas can be analyzed at the network level (Borgatti, Everett \& Johnson, 2013: 2-3).

In social network analysis, the criteria of centrality determine the influence of actors and indicate their strategic influence within a network (Tunçay \& Özer, 478-510: 495). This study performed network level analysis by employing eigenvector centrality, closeness centrality, and betweenness centrality, which are criteria commonly used in the literature.

Eigenvector centrality refers to the influence of a node in a network and takes values based on the number and influence of the nodes in the network. Eigenvector centrality depends not only on the number of ties but also on their nature so much so that a node with few high-quality ties contributes more than a node with many lower-quality ties (Codal \& Coşkun, 2016: 152). In Eigenvector centrality, a node is as central as its network. The centrality of a node is proportional to the sum of the centrality of its adjacent nodes. Eigen centrality can be interpreted as a measure of popularity in terms of tying a node with high eigenvector centrality to well-connected nodes (Borgatti, Everett, and Johnson, 2013: 179).

Closeness centrality is the sum of the geodesic distances (the shortest path from a node to all other nodes). In terms of closeness, small numbers indicate more central nodes (Borgatti, Everett, and Johnson, 2013: 183). According to the closeness-based approach, the more central a message in a network, the faster it spreads to the entire network (Codal and Coşkun, 2016: 149). In general, normalized closeness scores (N/closeness) are used in closeness centrality. A node with a high normalized closeness score is close to others, and therefore, information can potentially reach the central node very quickly from a random node. It is, therefore, an important advantage for a node to have high normalized closeness (Borgatti, Everett \& Johnson, 2013: 183).

Betweenness centrality refers to the extent to which a node falls in the shortest paths connecting all other nodes in a network (Freeman, 1978: 221). More specifically, it is the number of instances where the shortest route between two nodes passes through another node. If a node takes the shortest path between each pair of other nodes, then betweenness is maximum. Nodes with high ranges may deform information or interrupt the network, which may be considered a disadvantage, however, it can also be regarded as the power of the node in a suitable flow (Borgatti, Everett, and Johnson, 2013: 185). This study employed eigen, closeness, and betweenness centrality values to evaluate the concepts addressed by logistics studies. 
The National Thesis Center database was screened using the keyword of "logistics." The literature review yielded a total of 896 theses ( $167 \mathrm{PhD}$ and 729 master's). Two hundred and seventy-four articles were excluded because some were not permitted for publication while others had no keywords. The study sample, therefore, consisted of 622 studies published between 1997 and 2018. Data were analyzed using social network analysis on Gephi.

A network with 1764 unique nodes based on keywords and 4622 connections between the nodes was obtained from the sample.

Naturally, the term "logistics" was in the first place in terms of both degree and eigen score. It was already used as a keyword, and therefore, would be removed from analysis but was not removed because its bridges during networking. According to the table, most theses on logistics address reverse logistics, logistics management, logistics regression, supply chain management, logistics industry, outsourcing, logistics center, AHP, freight villages, logistics performance, foreign trade, quality, sustainability, and globalization. The term "logistic regression" bridge those themes the most.

The period from 1997 to 2018 was divided into three periods (1997-2010, 2011-2014, and 2015-2018) to analyze changes and to identify possible trends in terms of general perspective and research. The division of the period into three was also based on the total number of studies performed during that period.

"Transportation" and "reverse logistics" were the most important concepts with respect to betweenness centrality and closeness centrality, respectively, in the theses published between 1997 and 2010. "Logistics" had higher values on the list, however, it was ignored because it was a keyword.

There were 659 nodes and 1446 relationships between them in the studies between 2011 and 2014, which is in parallel to the increase in the number of studies in that period. As in the previous period, the concepts of supply chain management, reverse logistics, and logistics management were also important between 2011 and 2014, and regional studies (in Izmir, Mersin etc.) have become important. Different from the previous period, the concept of marketing stood out between 2011 and 2014. The concept of third party logistics first appeared in this period. This result shows that the concepts of marketing activities and third party logistics have become important in logistics since 2011.

The concepts in the theses published between 2015 and 2018 are not only related to logistics, but also about the whole business. The concepts of production and cost management were not in the rankings in the theses of the previous periods. However, they are important for betweenness centrality. This shows that the analysis of interdisciplinary activities is increasingly important for graduate theses. In this period, the concepts of sustainability, customer satisfaction, and e-commerce are used together with that of logistics.

This study employed social network analysis to analyze the keywords of 1990-2018 graduate theses on logistics. The results show that the most important concepts are supply chain management, outsourcing, logistics center, and reverse logistics. These concepts have been increasingly important since the publication of those theses.

However, the dynamic analysis performed to observe time-based changes shows that the concepts evolve from the logistics unit to the entire business, while regions evolve from companies and cities to the whole country in a way that it indicates a paradigm shift. Of course, many factors affect this. The first factor may be the need to bring a holistic perspective and to see the problem as a whole. The second factor may be that the researchers realized that basic problematics should be based on solid foundations and that they have the opportunity to focus on different topics as a result of developments in a field.

Logistics literature is nascent in Turkey but it is gaining momentum. This study portrayed the development of the field of logistics and showed that interdisciplinary studies become increasingly important. More global studies will be conducted in the future after the concepts of region and country are adequately examined.

The results show that studies have been conducted in every period on basic fields, such as supply chain management, logistics management, and reverse logistics. The studies on green supply chain management first appeared between 2015 and 2018. However, the theses did not focus on innovative logistics or logistics innovation, green logistics, urban logistics, humanitarian logistics, disaster logistics, logistics information technologies, logistics flexibility, agility, and integration. These areas are regarded as current 
approaches in logistics. Future studies should focus on these fields to contribute to the logistics literature because they play a key role in supplier-supplier and customer-customer chain at every stage of the logistics supply chain network. Logistics should be addressed in relation to all other disciplines for competitiveness, sustainability, and effective logistics management.

This study has three limitations. First, the study sample consisted only of graduate theses whereas articles and papers were not included. However, graduate theses on a field of study provide information about how developed that field of study is. It is, therefore, very important to analyze them. Second, some of the theses were not permitted for publication while others had no keywords, which reduced the sample size and limited the period of analysis to 1997 as the earliest date. Third, not all analysis data were reflected in the publications. The statistical results for network maps, the lowest of which has 577 lines, were not provided due to physical limits. Instead, the most important first 15 nodes were provided. Again, for the same reason, not all the images of the network maps but the sections containing only important nodes are given.

Keywords: Production Management, Social Network Analysis, Logistics, Supply Chain, Content Analysis

Öz: Bu çalışmanın amacı lojistik alanındaki çalışmaların, lisansüstü tezler bakımından gösterdiği değişimin bir haritasının oluşturulmasıdır. Çalışmanın amacına uygun olarak lojistik alanında 1990-2018 yılları arasında yayınlanan, yüksek lisans ve doktora tezlerine ilişsin künyeler derlenerek sosyal ağ analizine tabi tutulmuştur. Ulusal Tez Merkezi veri tabanında, alan bilgisi kısmında "lojistik" ifadesi yer alan çalışmaların tamamının künyeleri derlenmiş, 167'si doktora, 729’u yüksek lisans olmak üzere toplam 896 lisansüstü teze ulaş1lmıştır. Bunlardan yayımlama izni verilmemiş yayınlar ile anahtar kelime bilgisi bulunmayan çalışmalar çıkarıldığgnda toplam 622 adet eser çalışmaya dahil edilmiştir. Çalışmalarda belirtilen anahtar kelimeler üzerinden yapılan analizlerde en önemli kavramlar; tedarik zinciri yönetimi, dış kaynak kullanımı, lojistik merkez ve tersine lojistik olarak belirlenmiştir. Ayrıca çalışmalar üç döneme ayrılarak analiz edilmiştir. 1997-2010 yılları arasında en fazla çalışma yapılan anahtar kelimeler arasında tedarik zinciri yönetimi, lojistik yönetimi, tersine lojistik, depolama ve dış kaynak kullanımı tespit edilmiştir. 2011-2014 yılları arasında ise bu kavramlara ek olarak ilk defa pazarlama ve üçüncü parti lojistik anahtar kelimelerinin çalışılmış olduğu tespit edilmiştir. 20152018 yılları arasında ise lojistik ile ilgili yapılan çalışmaların daha çok disiplinler arası çalışmalara dönüştüğü bulgusu elde edilmiştir. Bu dönemde sürdürülebilirlik, müşteri memnuniyeti ve e-ticaret kavramlarının lojistik alanında çalışmalara dahil edildiği tespit edilmiştir. Yeşil tedarik zinciri yönetimi de ilk kez bu dönemde çalışılmaya başlanmıştır. Elde edilen bulgular lojistik alanında yapılan çalışmaların seyri hakkında bilgi vermektedir. Araştırma sonuçlarına göre lojistik alanında önemli olan ve çalışmalarda çok yer edinmediği tespit edilen lojistik inovasyon, yeşil lojistik, şehir lojistiği, insani yardım lojistiği gibi güncel konularda da çalışma yapılması gerektiği ile ilgili araştırmacılara önerilerde bulunulmuştur.

Anahtar Kelimeler: Üretim Yönetimi, Sosyal Ağ Analizi, Lojistik, Tedarik Zinciri, İçerik Analizi

\section{Giriş}

Günümüzde teknolojik ve ekonomik gelişmelerle birlikte firmalar daha geniş bir tedarikçi ve pazar ağına kavuşmuşlardır. Artan ticaret hacmi ile lojistik yönetiminin firmalar için önemi daha da artmıştır. Lojistik yönetimi, firmaların başarısında en önemli unsurlardan biridir.

Tedarik Zinciri Yönetimi Konseyi'nin tanımına göre, "lojistik yönetimi, müşterilerin gereksinimlerini karşılamak üzere, tedarik zinciri yönetiminin malların, hizmetlerin ve ilgili bilgilerin verimli akışını ve depolanmasını planlayan, uygulayan ve kontrol eden bir parçasıdır". Temel olarak, lojistik yönetimi, malların hareketinin kontrolü ve denetimidir. Bununla birlikte, yönetilen süreçlerin kapsamı bundan çok daha fazlasını kapsar. Nakliye yönetimi, navlun ve envanter yönetimi, malzeme taşıma ve sipariş yerine getirme gibi çok sayıda farklı faktör içerir.

Yönetim anlayışındaki değişmelerle birlikte lojistik, nakliyenin ötesine geçerek işletmede yürütülen satın alma, talep tahmini, stok planlama ve tahmini, sipariş süreci, depolama, ambalajlama, yükleme, taşıma, müşteri hizmetleri ve geri dönüşüm süreçlerini kapsayan bir kavram olmuştur. (Aslan, Taşçı ve Yıldız, 2018: 344) 
Başarılı bir lojistik yönetiminin, müşteri memnuniyetine, faaliyetlerin takip ve planlanabilirliğine, maliyetlerin düşmesine ve denetlenebilmesine olumlu katkılar sağlar. Lojistik faaliyetlerin firmalar için önemi bu alandaki bilimsel çalışmalara da yön vermiştir.

Bilim sosyolojisi bilimi, ortak norm ve kurallar aracılığıyla birbirine bağlı olan araştırmacıların, bilimsel bilgi üretimi gerçekleştirmek amacıyla yürüttüğü, organize ve sosyal faaliyetler olarak ele alır (Storer, 1966: 3). Başka bir deyişle, bilim camiası bir toplum veya sosyal bir kurum olarak kabul edilir (Moody, 2004). Topluluğun sosyal faaliyetleri, yeni üyelerin kabulü, grup normlarına uyum ve bilimsel bulguların paylaşımı ve işbirlikleri gibi konular araştırma konusu olarak karșımıza çıkmaktadır. Bilim sosyolojisinde, ișbirliği faaliyeti sadece bilginin üretilmesi açısından değil, aynı zamanda bilimsel toplumun refahı ve gelișimi için de önemlidir. Resmi ve gayri resmi etkileşimlerin ortaya çıkardığı işbirliği, bilimsel bir disiplinin sağlıklı olduğunun işaretidir. Buna bağlı olarak bir disiplinin varlığını sürdürebilmesi ve genişleyebilmesi için bir zorunluluk olan yeni üyelerin dahil edilmesi sağlanabilir (Crane, 1972: 117). Bunun yanı sıra, farklı alanlardaki bilim insanları arasındaki işbirlikleri, disiplin, kültür ve fiziki sınırlar gibi bariyerlerin kırılmasını kolaylaştırmaktadır (Heinze ve Kuhlmann, 2008); (Sonnenwald, 2007). Disiplinler arası işbirliği, farklı bilimsel topluluklar arasında köprüler kurulmasını, bilgi alışverişini ve yayılmasını mümkün k1lar (Lambiotte ve Panzarasa, 2009).

Bilimsel çalışmaların temelinde, var olan sistematik bilgi birikiminin belirlenmesi ve ilgili alana katkı sağlayacak çalışmaların yapılması yer alır. Bu yönüyle, var olan literatürün incelenmesi ve ortaya konması büyük önem arz etmektedir. Literatürde lojistik kavramı ile ilgili araştırmaları inceleyen çeşitli çalışmalar vardır. Acar ve Gürol (2013) çalışmalarında 1980-2011 yılları arasında Türkiye'de lojistik alanında yapılmış çalışmalar üzerinde içerik analizi yapılımıştır. Bu kapsamda ASOS ta taranan 257 makale ve YÖK veri tabanında bulunan 1506 tez çalışması değerlendirilmiştir. Çalışmada en çok ele alınan ilk üç kavramın sırasıyla Tedarik Zinciri Yönetimi, Envanter Yönetimi ve Ağ Tasarımı ve Dağıtım Yönetimi oluşturduğu bulunmuştur. Lojistik literatürüne ilişkin diğer bir çalışma ise Suvacı (2016) ULAKBİM üzerinden taranabilen dergilerde, Tedarik Zinciri ve Lojistik alanlarına ilişkin yapılmış çalışmaların bibliyometrik özelliklerini ortaya koymuştur. Çalışma kapsamında 47 dergide toplam 34 makaleye ulaşılmış ve değerlendirilmiştir.

Ulusal literatürde lojistik alanına ilişkin sosyal ağ analizini içeren bir çalışmaya rastlanamamıştır. Bununla birlikte farklı alanlara ilişkin çalışmaların sosyal ağ analizi ile incelendiği araştırmalar vardır.

Al, Sezen ve Soydal (2012) 1968-2009 yılları arası Hacettepe Üniversitesi atıflı çalışmaları bibliyometrik özellikleri açısından sosyal ă̆ analizi ile incelemekte, Hacettepe mensuplarının çalışmalarının zaman içerisindeki yönelimlerini değerlendirmektedir.

Demirgil ve Çetinkaya (2019)1975-2017 yılları arasında bölgesel kalkınma alanında SCI, SSCI ve AHCI indekslerinde taranan 158 Türkiye adresli çalışmayı sosyal ağ analizine tabi tutmuş, çalışmalarda öne çıkan yazar ve bölümler, kurumsal işbirliği düzeyi sosyal ağ analizi ve düğümlerin ağ yapı içerisinde merkezilik değerleri yardımıyla incelenmiştir.

Karagöz ve Yüncü (2013) turizm alanında yapılmış doktora tezlerine yönelik sosyal ă̆ analizinde, 1991-2010 yılları arasında Türkiye'de yapılmış çalışmaları incelemişler, yıllar itibariyle turizm alanındaki çalışmaların eğilimine ve araştırma konuları arasındaki ilişkilere yer vermişlerdir.

Turizm alanında yapılmış diğer bir çalışmada, Kervankıran, Eteman ve Serdağ (2019) 19752015 yılları arasında coğrafyacıların turizm alanında yazdığı 103 lisansüstü tez çalışmasının kaynakçasının sosyal ă analizi ile incelemiş, tez çalışmalarında kullanılan atıfların alanlara/disiplinlere göre dağılımı, disiplin içi ve disiplin dışı oranları ve tezlerin ulusal/uluslararası literatürden yararlanma durumunu ve atıfların disiplinler arası etkileşimi değerlendirilmiştir. 
Karagöz ve Kozak (2014) Anatolia Turizm Araştırmaları Dergisi’nde 1997-2010 yılları arasında yayınlanan makaleler üzerinden yaptıkları sosyal ağ analizinde turizm bilgi ağının yapısını, diğer alanlarla ilişkilerini ve akademik kurumlar arası ilişkileri incelemişlerdir.

Tunçay, Özer ve Tozkoparan (2015), yönetim ve organizasyon alanında ulusal literatürde yer alan ve konu başlı̆̆ında "sosyal sermaye" kavramı geçen makaleleri incelemişlerdir. Çalışmada 69 makaleye anahtar sözcüklerinden hareketle bibliyometrik analiz yapılmış, anahtar sözcüklerin ağ yapısını görselleştirmek amacıyla sosyal ağ analizi kullanılmıştır. Ayrıca, tez başlığında "sosyal sermaye" kavramı geçen ulusal tezler taranmış ve ulaşılan tezler, yayınlandıkları yıllar, çalışılan disiplinler ve tez türü açısından genel bir değerlendirmeye tabi tutulmuştur. Ulusal literatürde lojistik alanına ilişkin sosyal ağ analizini içeren bir çalışmaya rastlanamamıştır. Bununla birlikte yabancı literatürde sınırlı sayıda çalışmaya ulaşılmıştır.

Ataman ve Çelik (2018)2000-2015 yılları arası WoS veri tabanında yer alan Yüzüncü Yı1 Üniversitesi ve Van adresli çalışmaları sosyal ağ analizi ile incelemiştir.

Uluslararası literatür incelendiğinde ise lojistik alanında sosyal ağ analizine yönelik sınırlı sayıda çalışmaya ulaşılmıştır.

Phillips ve Phillips (1998) yaptıkları çalışmada lojistik ve taşımacılık alanındaki çalışmaların zaman içerisindeki değişimini incelemek için sosyal ağ analizinden faydalanmıştır. Araştırma sonucu, alana ilişkin çalışmalar iki dönem içerisinde değerlendirilmiştir. İlk dönemde nakliye ve lojistik birbirinden daha bağımsız iken ikici dönemde lojistik ve taşımacılık arasında artık belirgin bir kopuş olmadığı, lojistik ve taşımacılık dergilerinin ağın merkezine çok yakın bir yerde bulunduğu belirtilmiştir.

Borgatti ve Li (2009) yaptıkları çalışmada tedarik zinciri kuramı üzerinden sosyal ağ analizinin kullanımını incelemişlerdir. Çalışmada malzeme ve para akışı gibi sert bağlarının yanı sıra arkadaşlık ve bilgi paylaşımı gibi yumuşak bağ türlerine yer verilmiştir.

Kima vd. (2011) otomotiv sektöründe tedarik zincirine yönelik vaka analizi yapan bir çalışmanın verilerini kullanarak, tedarik ağlarının yapısını incelemek için sosyal ağ analizinden faydalanmışlardır. Çalışmada sosyal ağ analizi ile birbirine bağlı alıcı ve tedarikçiler sisteminin, bir ağ olarak doğrusal bir zincirden daha iyi modellendiği belirtilmiştir.

Alvarez ve Serrato (2013) Latin Amerika'daki insani lojistik operasyonlarında yer alan kuruluşlardaki iletişim modellerinin analizi için Sosyal A $\breve{g}$ Analizinden faydalanılmıştır. Bu kapsamda Meksika, Panama ve Şili’ deki ağ yapılarını tanımlamak ve analiz etmek için iletişim politikalarını ve modellerini karşılaştırmak üzere bir model sunulmuşlardır.

Wichmann ve Kaufmann (2016) yaptıkları çalışmada 20 yıllık bir periyod için tedarik zinciri yönetimi alanında yayınlanan 11 üst düzey dergiyi incelemişlerdir. Tedarik zinciri yönetimi alanında sosyal ağ analizinin uygulanabilirliğine yönelik yapılan çalışmada, sosyal bilimler alanında sosyal ağ analizinin kullanılmasında 2010 yılından itibaren bir ivmelenme olduğu ancak tedarik zinciri yönetimi alanında çalışmaların henüz yeterli olmadığı, yöntemin tadrik zinciri alanında kullanılmasının faydalı olacağı ve alana özgü karmaşık ilişkiler hakkında daha detaylı bilgilerin edinilmesine katkı sağlayacağı belirtilmiştir.

\section{Yöntem ve Bulgular}

Bir alanda yayımlanan akademik tezler o alanda var olan paradigmalara ilişkin ipuçları içerir. $\mathrm{Bu}$ paradigmaların ortaya konulması hem alanın gelişiminin ortaya konulması hem de ilerleyen dönemlerde yapılacak çalışmalara yol göstermesi bakımından önem taşır. Bu çalışmada lojistik alanının lisansüstü tezler bakımında gösterdiği değişimin bir haritasının oluşturulması amaçlanmıştır. 
A $\breve{g}$ araştırmaları için veri toplamada anketlerden faydalanılabileceği gibi web tabanlı araştırma ve arşiv çalışmaları yapılabilir (Ağcasulu, 2018: 1918). Bu çalışmada, çalışmanın amacına uygun olarak, Ulusal Tez Merkezinde yer alan, 1990-2018 y1lları arasında, lojistik alanında yayımlanmış yüksek lisans ve doktora tezlerine ilişkin künyeler derlenerek sosyal ağ analizine tabi tutulmuştur.

Sosyal ağ, düğümlerden (bireyler veya elemanlar) oluşan ve bu düğümleri aralarındaki ilişki ve etkileşimlere bağlı olarak birbirine bağlayan bir yapıdır. Bu yapı içerisindeki unsurların birbirleri ile olan ilişkilerin bilimsel yöntemlerle incelenerek anlamlı sonuçlar elde edilmesine sosyal ağ analizi denir. Sosyal ă analizi yazılımları karmaşık yapıya sahip birçok verinin analizini ve görselleştirilmesini sağlar. (Tekdal, Baz ve Saygıner, 2017)

Ağ analizinin temeli grafik kuramına dayanır. İstenileni açıklamada iyi yapılandırılmış bir grafik kelimelerden daha etkilidir. Sosyal ağ analizinde aktörler ve ilişkiler doğrultusunda ortaya çıkan ağ haritasına sosyagram adı verilir. Sosyogramlar aktörler arası ilişkileri gösterirken, kıyaslamaya yardımcı olmakta, sayısal analizlere yol göstermekte, verilerin genel yapısını ortaya koymaktadır. Uluslararası bir dil ile konuyu bir bütün olarak ortaya koyarak zaman tasarrufu sağlamaktadır. (A ğcasulu, 2018: 1919-1920)

Ağ analizinde çift, düğüm ve ağ olmak üzere üç düzey analiz vardır. Çift düzeyi iki aktör arasındaki ilişkiyi incelerken düğüm düzeyinde aktörlerin diğer aktörlerle ilişki sayıları dikkate alınmaktadır. A $\breve{g}$ düzeyinde ise ağda yer alan tüm düğüm ve çiftler dikkate alınmaktadır. İyi bağlanmış ağların fikirlerin yayılımındaki etkisi bu düzeyde incelenebilir. (Borgatti, Everett, ve Johnson, 2013: 2-3)

Sosyal ağ analizinde merkezilik ölçütleri, aktörlerin ağ içerisindeki önem düzeyini belirleyen ölçütlerdendir ve her hangi bir aktörün konum itibariyle ağ içerisindeki stratejik önemini gösterir. (Tunçay ve Özer, 478-510: 495)

Eigen Merkeziliği herhangi bir düğümün ağdaki öneminin ölçüsü olup, ağdaki düğümlere bağlantının sayısı ve niteliği doğrultusunda değerler alır. Eigen merkeziliği bağların sayısına olduğu kadar niteliğine de bağlıdır, öyle ki bir düğümün az sayıda yüksek kaliteli bağlantısı varsa, çok sayıda daha düşük kalitede bağlantıya sahip düğ̈̈me oranla daha fazla katkı sağlar. (Codal ve Coşkun, 2016: 152) Eigen merkeziliği söz konusu olduğunda, bir düğüm sadece ağ 1 kadar merkezidir. Her bir düğümün merkeziyeti bitişik olduğu düğümlerin merkezliliklerinin toplamı ile orantılıdır. Eigen merkeziyeti, eigen merkeziliği yüksek olan bir dügümün, kendileriyle iyi bağlanmış düguümlere bağlanması anlamında bir popülerlik ölçüsü olarak yorumlanabilir. (Borgatti, Everett, ve Johnson, 2013: 179)

Yakınlık merkeziyetini bir düğümden diğerlerine jeodezik mesafelerin (iki düğümü birleştiren en kısa yol) toplamıdır. Yakınlık ölçüsü bakımından küçük sayılar düğümün daha merkezi olduğunu gösterir. (Borgatti, Everett, ve Johnson, 2013: 183) Yakınlık tabanlı yaklaşıma göre, ağdaki en merkezi pozisyondaki mesaj minimum sürede tüm ağ boyunca yayılır. (Codal ve Coşkun, 2016: 149) Yakınlık merkeziyeti kullanılırken çoğunlukla normalleştirilmiş yakınlık skoru kullanılır(N/yakınlık). Yüksek normalleştirilmiş yakınlık skoruna sahip bir düğüm diğerlerine kısa bir mesafedir, bu nedenle rastgele bir düğümden çıkan bilgi potansiyel olarak merkezi düğüme çok hızlı bir şekilde ulaşabilir. Bu nedenle, yüksek bir normalleştirilmiş yakınlık, bir düğüm için önemli bir avantaj olarak görülmektedir. (Borgatti, Everett, ve Johnson, 2013: 183)

Arasındalık merkeziliği, bir noktanın, onları bağlayan en kısa veya jeodezik yollardaki diğer nokta çiftleri arasına düşme sıklı̆̆ına dayanır. (Freeman, 1978: 221) Daha spesifik olarak, belirli bir odak düğümü için, odak düğümü dışındaki her bir düğüm çifti için, birinden diğerine en kısa yolların tümünün odak düğümünden kaç defa geçtiği hesaplanarak bulunur. Düğüm, diğer her düğüm çifti arasındaki en kısa yol boyunca uzanıyorsa, arasındalık maksimum değerine ulaşır. Yüksek aralığa 
sahip düğümler, bilgileri deforme etme yada ağı kesintiye uğratabilme yönüyle olumsuz olarak değerlendirilebileceği gibi uygun bir akış ortamında düğümün gücü olarak ta değerlendirilebilir. (Borgatti, Everett, ve Johnson, 2013: 185) Çalışmada lojistik alanındaki çalışmalarda le alınan kavramların değerlendirilmesinde eigen, yakınlık ve arasındalık merkeziliği değerleri kullanılmıştır.

Çalışmada Araştırmanın ilk kısmın olan veri toplanması aşamasında Ulusal Tez Merkezi veri tabanında alan bilgisi kısmında "lojistik" ifadesi yer alan çalışmaların tamamının künyeleri derlenmiş ve sonuçta 167'si doktora, 729'u yüksek lisans olmak üzere toplam 896 lisansüstü teze ulaşılmıştır. Bunlardan yayımlama izni verilmemiş yayınlar ile anahtar kelime bilgisi bulunmayan çalışmalar çıkarıldığında toplam 622 adet eser çalışmaya dahil edilmiştir. Bu 622 eserin gerek imla yanlışları gerekse de alan ile ilgili olup olmadıklarının detaylı bir şekilde incelenmesi araştırmacılar tarafından manuel olarak yapılmıştır.

Derlenen tezlere ilişkin demografik bulgular aşağıda verilmiştir.

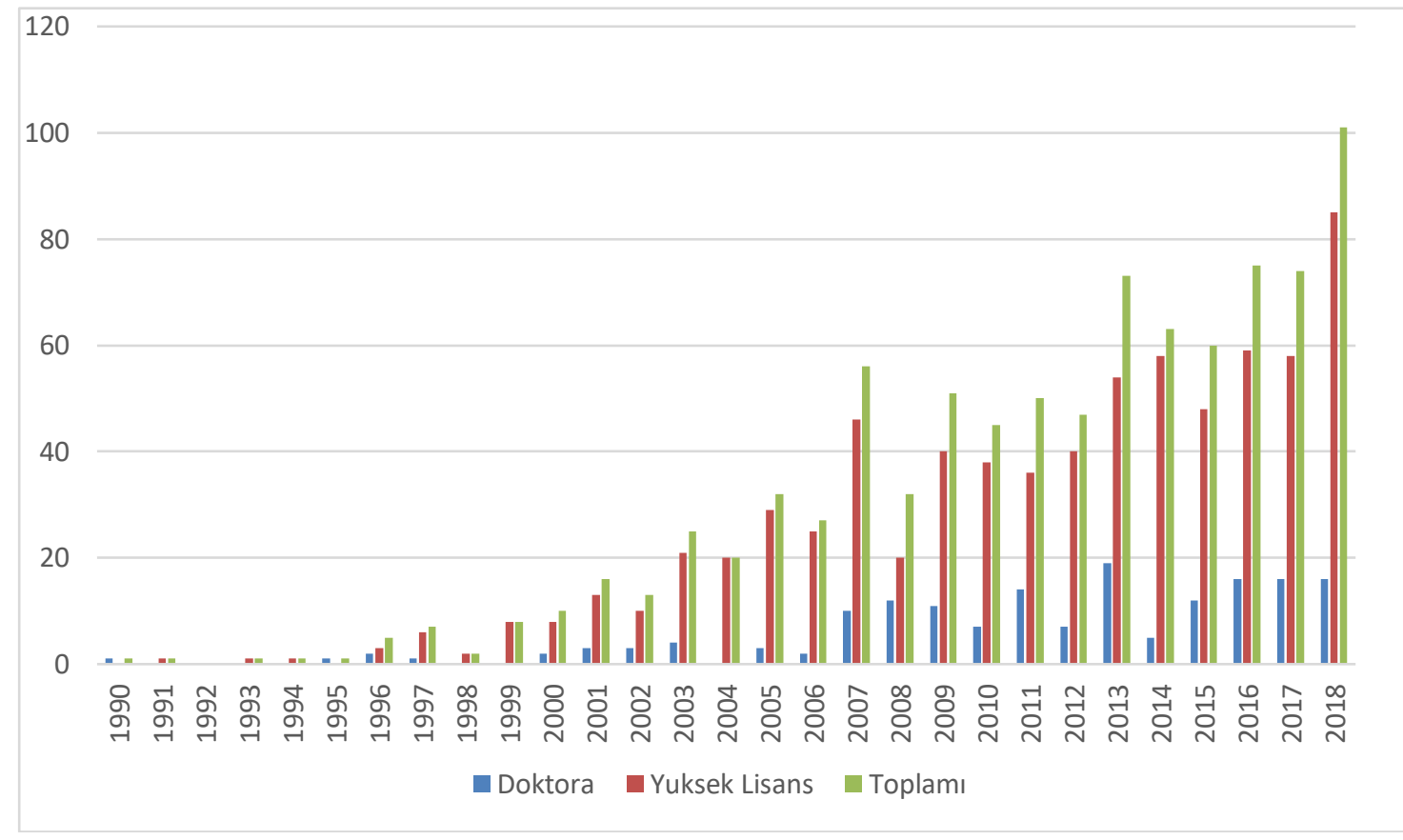

Şekil 1: Tezlerin Y1llara Göre Dağılımı

Lojistik alanında yazılan tez sayısında genel anlamda sürekli bir artış olmakla beraber en çok tezin yazıldığ yıl Şekil 1'de görüldüğüü üzere 2018'dir. 
Tablo 1: Tezlerin Üniversitelere Göre Dağılımı

\begin{tabular}{lrrr}
\hline Üniversite & Doktora & Yüksek Lisans & Toplam \\
\hline Dokuz Eylül Üniversitesi & 20 & 60 & 80 \\
\hline Marmara Üniversitesi & 13 & 56 & 69 \\
\hline İstanbul Teknik Üniversitesi & 7 & 54 & 61 \\
\hline Gazi Üniversitesi & 12 & 34 & 46 \\
\hline İstanbul Üniversitesi & 10 & 33 & 43 \\
\hline Yıldı Teknik Üniversitesi & 11 & 26 & 37 \\
\hline Kara Harp Okulu Komutanlığı & 2 & 17 & 19 \\
\hline Okan Üniversitesi & 2 & 17 & 19 \\
\hline Maltepe Üniversitesi & 4 & 13 & 17 \\
\hline Bahçeşehir Üniversitesi & - & 16 & 16 \\
\hline İstanbul Ticaret Üniversitesi & - & 16 & 16 \\
\hline Selçuk Üniversitesi & 5 & 11 & 16 \\
\hline Hacettepe Üniversitesi & 9 & 5 & 14 \\
\hline Uludağ Üniversitesi & 3 & 11 & 14 \\
\hline Ankara Üniversitesi & 5 & 8 & 13 \\
\hline Beykent Üniversitesi & 1 & 12 & 13 \\
\hline Dumlupınar Üniversitesi & 3 & 10 & 13 \\
\hline Anadolu Üniversitesi & 4 & 8 & 12 \\
\hline Eskişehir Osmangazi Üniversitesi & 4 & 8 & 12 \\
\hline Yaşar Üniversitesi & 2 & 10 & 12 \\
\hline Boğaziçi Üniversitesi & 2 & 9 & 11 \\
\hline Gaziantep Üniversitesi & 2 & 9 & 11 \\
\hline Gebze Yüksek Teknoloji Enstitüsü & 4 & 6 & 10 \\
\hline İzmir Ekonomi Üniversitesi & 1 & 9 & 10 \\
\hline Orta Doğu Teknik Üniversitesi & 1 & 10 & 10 \\
\hline Süleyman Demirel Üniversitesi & 2 & 292 \\
\hline Diğer Üniversiteler & 38 & 896 \\
\hline Toplam & & 9 & \\
\hline & 4 & 9 & 10 \\
\hline
\end{tabular}

Lojistik alanında yazılan tezlerin üniversitelere göre dağılımını gösteren Tablo 1'e göre bu konuda 20 doktora ve 60 yüksek lisans tezi ile Dokuz Eylül Üniversitesi başı çekmektedir. Bunu 13 doktora 56 yüksek lisans tezi ile Marmara Üniversitesi ve 7 doktora 54 yüksek lisans tezi ile İstanbul Teknik Üniversitesi takip etmektedir. Toplamda 167 farklı üniversiteden lisansüstü düzeyinde, lojistik alanında tez yazılmışıır.

Tablo 2: Tezlerin anabilim dallarına göre dağılımı

\begin{tabular}{lrrr}
\hline Anabilim Dalı & Doktora & Yüksek Lisans & Toplam \\
\hline İşletme & 68 & 253 & 321 \\
\hline Endüstri Mühendisliği & 21 & 121 & 142 \\
\hline Uluslararası Ticaret ve Lojistik & 4 & 89 & 93 \\
\hline Deniz İşletmeciliği & 10 & 41 & 51 \\
\hline İstatistik & 9 & 39 & 48 \\
\hline İktisat & 9 & 34 & 43 \\
\hline Diğer Alanlar & 46 & 153 & 169 \\
\hline Toplam & 167 & 730 & 867 \\
\hline
\end{tabular}

Yazılan bu tezlerin dahil oldukları anabilim dalları incelendiğinde 167 farklı alan bilgisine ulaşılmıştır. Anabilim dalları arasında İşletme, 68 doktora ve 253 yüksek lisans tezi ile lojistik alanında en fazla tezin yazıldığı anabilim dalı olarak tespit edilmiştir. İşletme bölümünü 21 doktora ve 121 yüksek lisans tezi ile Endüstri Mühendisliği Bölümü ve 4 doktora 89 yüksek lisans tezi ile Uluslararası Ticaret ve Lojistik Bölümü takip etmektedir. 
Ayıklanan ve temizliğe tabi tutulan veri seti Gephi programı aracılığı ile sosyal ağ analizine tabi tutulmuştur. Burt (2005: 12)'a göre bir sosyogram, insan etkileşimlerinin "ağ tortusu" nu göstermektedir. Bireyleri ifade eden düğümleri birbirine ilişkilendiren bağlar (kenarlar) bir ilişkinin göstergesidir; bu bağlar tek yönlü veya çift yönlü (yönlendirilmemiş) olabilir ve güçlü veya zayıf olabilirler. Bir ilişki sosyal ağ analizi araçları tarafından işlenebilecek hale getirilebildiği durumlarda matematiksel prensipler de bu ilişki üzerinde uygulanabilir (Lin, Fu, ve Hsung, 2001: 63). Bu sayede; ağa ait yoğunluk, yapısal boşluklar, köprüler gibi alandaki paradigmaların yapısını oluşturan unsurlar analiz araçlarının vasıtasıyla görünür hale getirilebilir.

Yapılan veri temizliği sonucunda analize uygun olan 1997 ve 2018 y1lları arasında yayımlanmış 622 yüksek lisans ve doktora tezine ait anahtar kelimelerin oluşturduğu 1764 benzersiz düğüm ve bu düğümler arasında yer alan 4622 bağlantı içeren bir ağ elde edilmiştir. Hem görselleştirmenin kolaylığı hem de kümelenmelerin daha iyi belirtilebilmesi adına Circle Pack düzeni tercih edilmiştir. Oluşturulan bu ağa iliş̧kin harita Şekil 2'de verilmiştir.

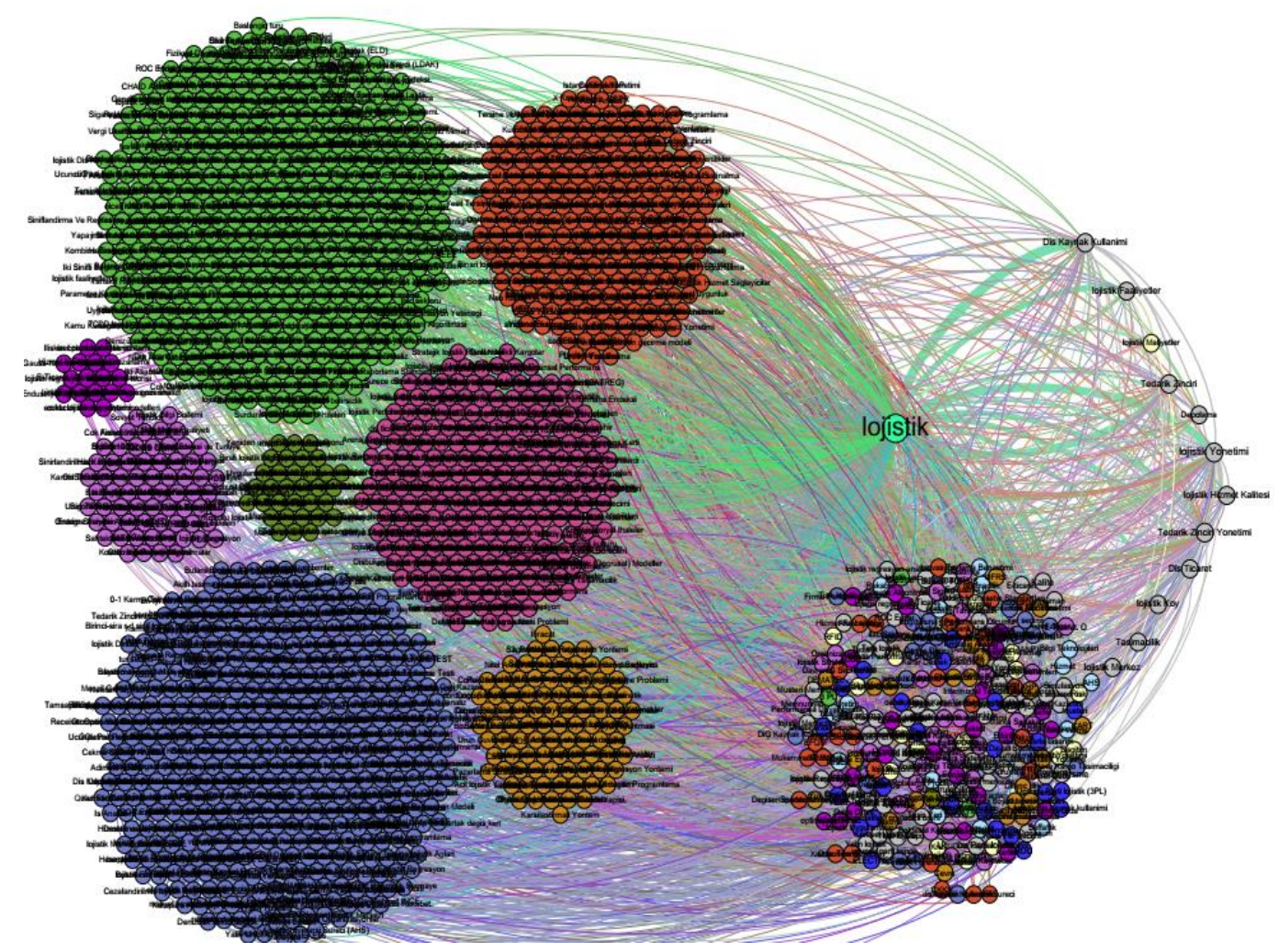

Şekil 2: 1997-2018 Yıllarına Ait Ağ Haritas1

Elbette yapısal açıdan farkıı bir ortama taşınması durumunda görsel bir kaybın yaşanması olağandır. Bundan dolayı kritik sayılabilecek düğümlere ilişkin daha detaylı bir görsel aşağıda Şekil 3 'te yer almaktadır. 


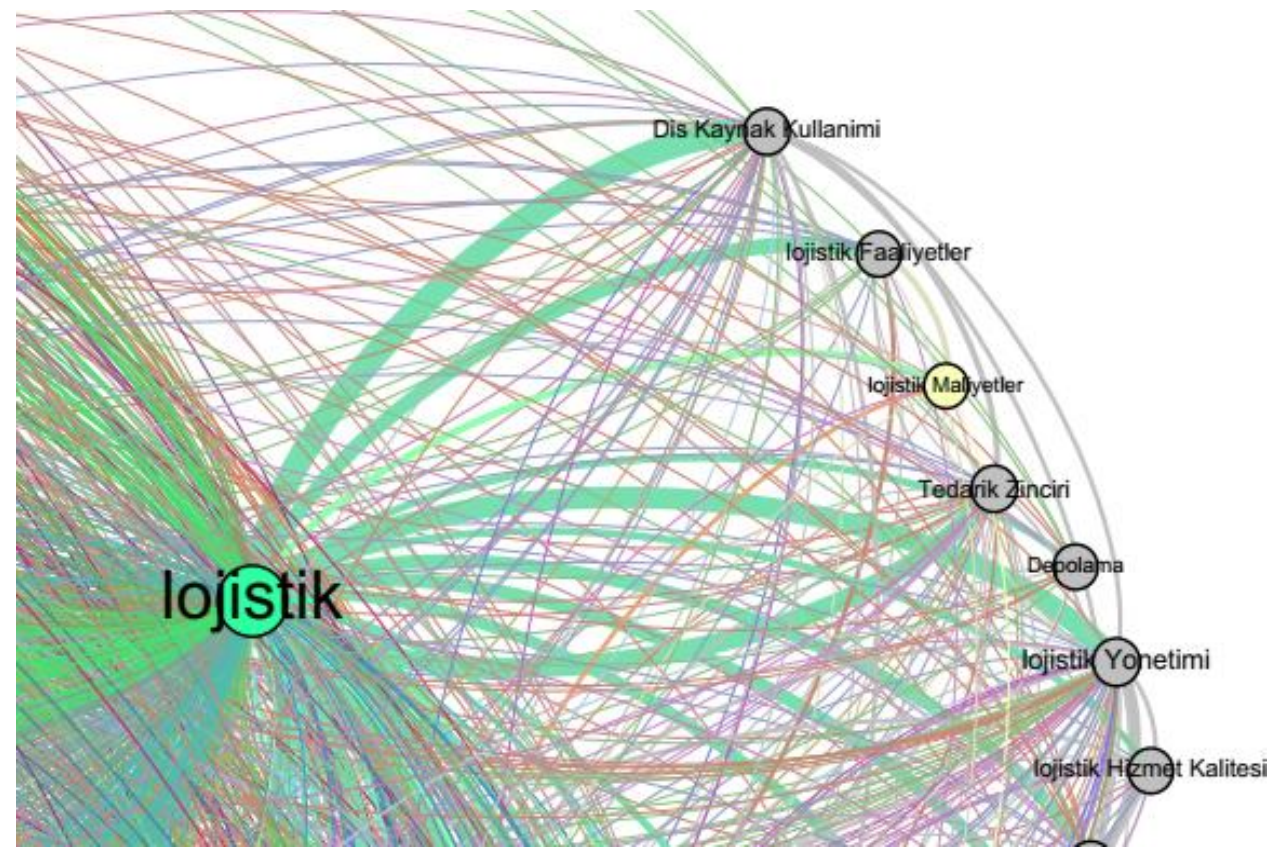

Şekil 3: 1997-2018 Y1lları Kritik Dügümlere Ait Ağ Haritası

$\mathrm{Bu}$ görseller Ulusal Tez Merkezi veri tabanında yer alan lojistik alanıyla alakalı olarak yazılmış lisansüstü tezlerinin genel bir resmini vermektedir. Yukarıda verilen görsellere ilişkin istatistiki bulgular Tablo 3'de yer almaktadır.

Tablo 3: Tüm Yıllara Ait Merkezilik Ölçütleri

\begin{tabular}{lrlll}
\hline Etiket & Derece & Yakınlık Merkeziliği & Arasındalık Merkeziliği & Eigen Merkeziliği \\
\hline Lojistik & 601 & 0.5290222049084534 & 0.48672773183295504 & 1.0 \\
\hline Tersine Lojistik & 90 & 0.38285875387651536 & 0.05954629562825264 & 0.11423121009130109 \\
\hline Lojistik Yönetimi & 80 & 0.39271255060728744 & 0.030341708533160216 & 0.16256898512079213 \\
\hline Lojistik Regresyon & 77 & 0.31945424605975065 & 0.070634444452392187 & 0.05010148076010927 \\
\hline Tedarik Zinciri Yönetimi & 75 & 0.3923721467783878 & 0.06459425303807426 & 0.1394748385069846 \\
\hline Lojistik Sektörü & 48 & 0.3610741823982983 & 0.0315141916900109 & 0.08523393111355676 \\
\hline Diş Kaynak Kullanımı & 46 & 0.375968992248062 & 0.01190837340556427 & 0.11299184340345376 \\
\hline Lojistik Merkez & 38 & 0.37369290038525044 & 0.0139001435811121162 & 0.08798494493011445 \\
\hline AHP & 35 & 0.30011049723756905 & 0.009262097964610605 & 0.04663169804871567 \\
\hline Lojistik Köy & 35 & 0.3612662942271881 & 0.009200882059897867 & 0.08310505292544562 \\
\hline Lojistik Performans & 34 & 0.3596398305084746 & 0.01792752347765734 & 0.06953759180699154 \\
\hline Diş ticaret & 32 & 0.3651519225598279 & 0.004515675852861923 & 0.08816281717237662 \\
\hline Kalite & 27 & 0.35868991019545693 & 0.0013696517246531532 & 0.08540104165139661 \\
\hline Sürdürülebilirlik & 26 & 0.3795416433761878 & 0.009141250967108586 & 0.07951419690714197 \\
\hline Küreselleşme & 25 & 0.3758649321893164 & 0.0050946706356500265 & 0.08610146329576283 \\
\hline
\end{tabular}

Lojistik ifadesinin hem derece hem de eigen skoru bakımından ilk sırada olması beklenen bir durumdur. $\mathrm{Bu}$ ifadenin hali hazırda arama terimi olarak kullanılmasından dolayı analizden çıkarılması düşünülmüssse de ağın oluşumu sırasında oluşturduğu köprüler nedeniyle bundan vazgeçilmiştir. Bu tabloya göre lojistik alanında tezler bakımından en çok irdelenen konular arasında "tersine lojistik, lojistik yönetimi, lojistik regresyon, tedarik zinciri yönetimi, lojistik sektörü, dış kaynak kullanımı, lojistik merkez, AHP, lojistik koy, lojistik performans, dış ticaret, kalite, sürdürülebilirlik ve küreselleşme" yer almaktadır. Bu konuların birbiri arasında köprü vazifesi görmesi bakımından en yüksek düzeye "lojistik regresyon" ifadesi sahiptir. 
Genel bakışın yanı sıra araştırmada, bu noktaya gelinene değin yaşanan değişimin irdelenmesi ve olası gidiş yönünün belirlenmesi amacıyla bahsi geçen zaman aralığı, dönem içerisinde yapılan toplam çalışma miktarları dikkate alınarak, üç dönemde ayrı ayrı analize tabi tutulmuştur.

1997-2010 yılları arasında yayımlanan lisansüstü tezlerine ilişkin oluşturulan ağa ilişkin analiz sonuçları aşağıda yer almaktadır.

577 dügümm ve 1235 kenardan oluşan bu ağa ilişkin olarak, ağda öneme sahip düğümlerin yer aldığ görsel Şekil 4’te verilmiştir.

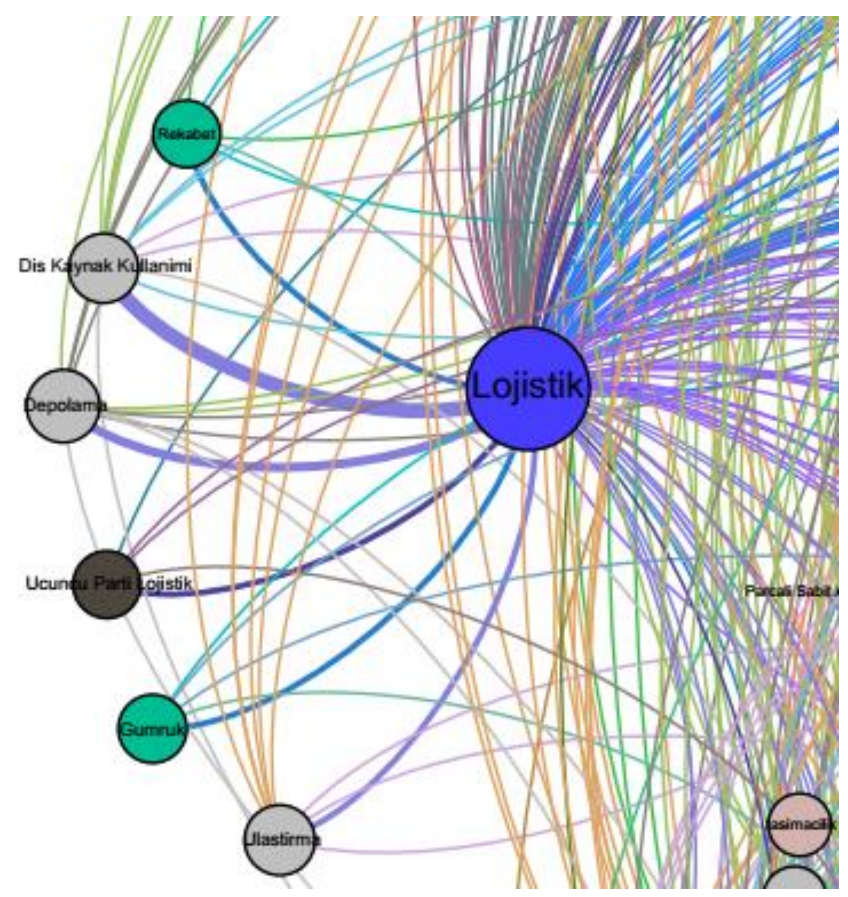

Şekil 4: 1997-2010 Yılları Arası A $\breve{g}$ Haritası

Oluşturulan ağa ilişkin istatistiki veriler Tablo 4'de yer almaktadır.

Tablo 4: 1997-2010 Yı1ları Arası Anahtar Kelimelerin Ağına İlişkin Merkezilik Ölçütleri

\begin{tabular}{|c|c|c|c|}
\hline Etiket & Yakınlık Merkeziliği & Arasındalık Merkeziliği & Eigen Merkeziliği \\
\hline Lojistik & 1310.48355263157894735 & 0.19552335223687523 & 1.0 \\
\hline Lojistik Yönetimi & 210.39783491204330174 & 0.040433350762400316 & 0.20023113813917146 \\
\hline Lojistik Regresyon & 190.40625 & 0.004065893866976906 & 0.03774632658931281 \\
\hline Tedarik Zinciri Yönetimi & 180.31210191082802546 & 0.022441042206803555 & 0.07629215487508371 \\
\hline Depolama & 140.40384615384615385 & 0.024353446819309472 & 0.1876689130924389 \\
\hline Güvenilirlik & 121.0 & 0.02098912763188 & 0.03310760469254194 \\
\hline Dış Kaynak Kullanımı & 120.33676975945017185 & 0.005517142120381642 & 0.1325231640895503 \\
\hline Tersine lojistik & 121.0 & 0.0335826042110 & 0.01739424398107098 \\
\hline Ağ Tasarımı & 120.3391 & 7586983276009 & 0.12876079882769245 \\
\hline Kalite Evi & 110.3823146944083225 & 0.009280354681037127 & 0.17434506110171505 \\
\hline Tam Zamanında Üretim & 110.3479289940828402 & 0.006956396586568158 & 0.13866408678216535 \\
\hline Barkod & 100.3828125 & 0.06138420298285488 & 0.1202422441447088 \\
\hline Tavlama Benzetimi & 100.29458917835671344 & 0.0032173334212877696 & 0.0578850566057163 \\
\hline Ulaştırma & 100.3295964125560538 & 0.0739720424819 & 0.1457533268899711 \\
\hline Risk Faktörleri & 90.4482758620689655 & 0.004029912505322243 & 0.027806304240245133 \\
\hline
\end{tabular}


Derece bakımından önem düzeylerine göre en yüksek değere sahip ilk 15 anahtar kelimenin ve bu kelimelere bağlı istatistiki değerlerin yer aldığı Tablo 2'de ağ açısından öneme sahip olduğu düşünülen "ulaştırma" ifadesi Arasındalık merkeziliği bakımından en önemli ifade olurken, "tersine lojistik" ifadesi yakınlık merkeziliği bakımından en önemli ifade olarak tespit edilmiştir. "Lojistik" anahtar kelimesi her ne kadar bu listede daha yüksek değerler elde etmişse de arama kelimesi olması bakımından göz ardı edilmesi uygundur. Listeden ve analizden çıkarılmayışının nedeni önceki kısımlarda açıklanmıştır.

Zaman dilimlerinden ikincisi olarak 2011-2014 yıllarına ait anahtar kelimelerin ağ haritasının önemli düğümlerinin yer aldığı görseli Şekil 5’te verilmiştir.

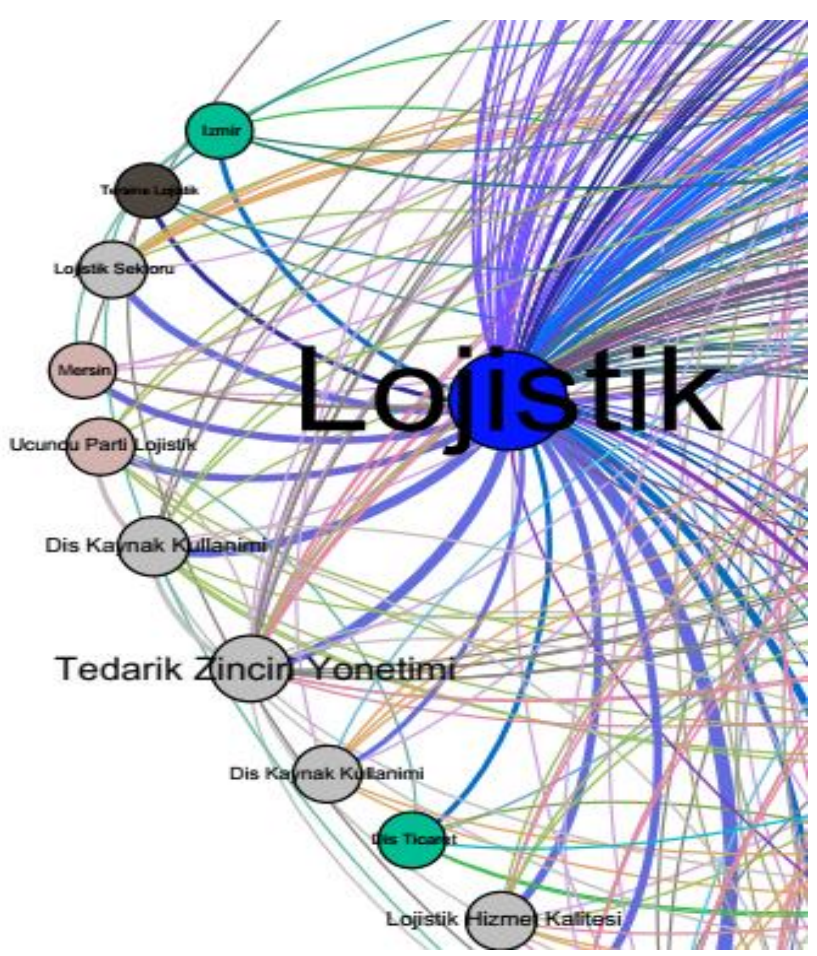

Şekil 5: 2011-2014 Yılları Aras1 Ağ Haritas1

2011-2014 y1lları arasında artan yayın sayısıyla orantılı olarak 659 düğüm ve bu düğümler arasında yer alan 1446 ilişkinin varlığı tespit edilmiştir.

İlgili döneme ait anahtar kelimelerin istatistiki bulguları Tablo 5'te yer almaktadır. 
Tablo 5: 2011-2014 Yı1ları Arası Anahtar Kelimelerin Ağına İlişkin Merkezilik Ölçütleri

\begin{tabular}{lclll}
\hline Etiket & Derece & Yakınlık Merkeziliği & Arasındalık Merkeziliği & Eigen Merkeziliği \\
\hline Lojistik & 133 & 0.4798890429958391 & 0.17812045246691424 & 1.0 \\
\hline Tedarik Zinciri Yönetimi & 35 & 0.4199029126213592 & 0.04866164203969426 & 0.3421902520237471 \\
\hline Tersine Lojistik & 24 & 0.875 & 0.0014913934489048297 & 0.046898915743135476 \\
\hline Lojistik Yönetimi & 24 & 0.4061032863849765 & 0.03275580015647601 & 0.2772965731083642 \\
\hline AHP & 17 & 0.2987910189982729 & 0.019515565365337748 & 0.05538192451936771 \\
\hline Dış Kaynak Kullanımı & 17 & 0.37445887445887444 & 0.010802685892353439 & 0.19746891547053882 \\
\hline Lojistik Regresyon & 17 & 1.0 & 0.00492021888076 & 0.037121082414342116 \\
\hline Lojistik Hizmet Kalitesi & 15 & 0.35523613963039014 & 0.006370865596874154 & 0.1840074814731339 \\
\hline Lojistik Koy & 14 & 0.4046783625730994 & 0.042799075601875916 & 0.151844364771503834 \\
\hline Pazarlama & 11 & 0.3914027149321267 & 0.007401472867399195 & 0.1932748719676008 \\
\hline Hizmet Kavram1 & 110.3537832310838446 & 0.008724064111 & 0.17566475078943006 \\
\hline Üçüncü Parti Lojistik & 90.36459430979978924 & 0.00562397321260613 & 0.15395867873260186 \\
\hline Toplam Kalite Yönetimi & 90.27287066246056785 & 0.005508805812295949 & 0.02623815804249022 \\
\hline Mersin & 90.3270321361058601 & 0.00459833540258426 & 0.12437178617714993 \\
\hline İzmir & 80.3267233238904627 & 0.00275900124155 & 0.12409984848920946 \\
\hline
\end{tabular}

Önceki dönemle benzer olarak tedarik zinciri yönetimi, tersine lojistik, lojistik yönetimi gibi kavramlar ilgili dönemde de önemini korurken, İzmir ve Mersin gibi bölgesel çalışmalar önem kazanmaya başlamıştır. Ayrıca bir önceki dönemde ön sıralarda yer almayan farklı bir alan olarak pazarlama bu dönemde ön plana çıkmıştır. Ayrıca üçüncü parti lojistik ifadesinin de ilk defa bu dönemde ortaya çıtığı görülmektedir. Bu bulgu 2011 yılından itibaren lojistik alanında pazarlama faaliyetlerine ve üçüncü parti lojistik kavramına önem verilmeye başlandığını göstermektedir.

Son dönem olarak ele alınan 2015-2018 yılları arasında yayımlanmış lisansüstü tezlerin anahtar kelimelerine ilişkin oluşturulan ağ haritasında öneme sahip düğümlerin yer aldığı görsel Şekil 5'te yer almaktadır.

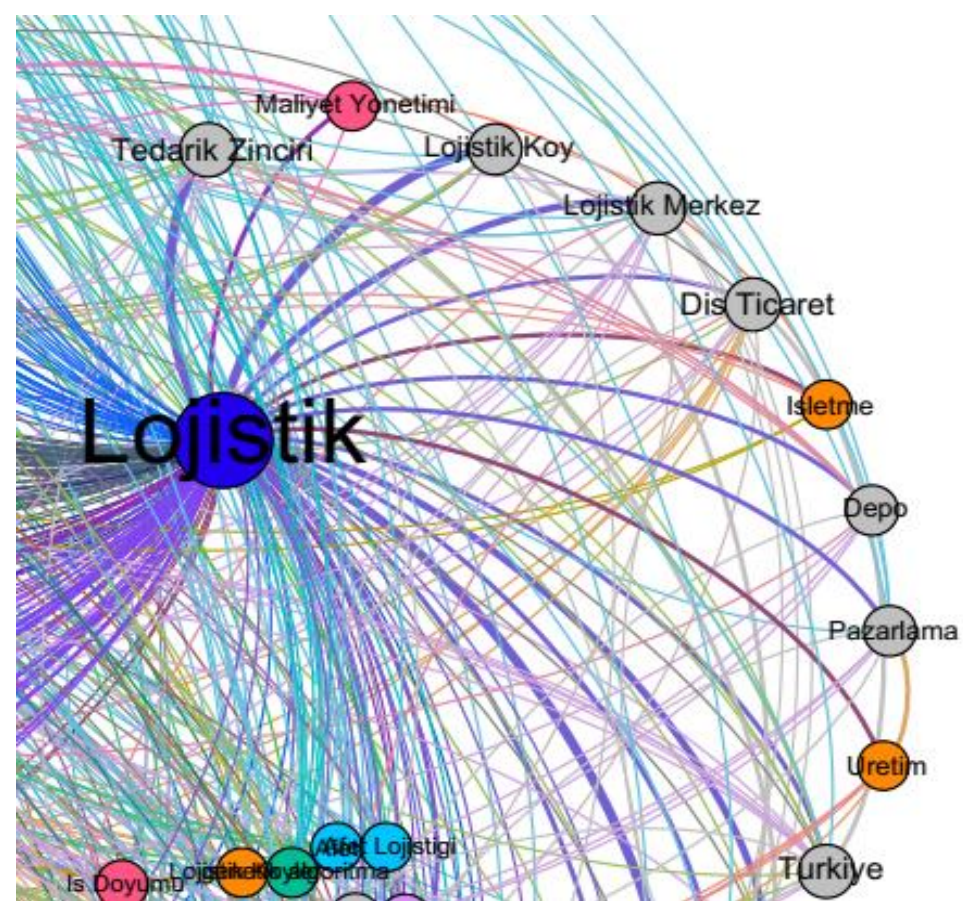

Şekil 6: 2015-2018 Y1lları Arası Ağ Haritası 
Toplam 853 düğüm ve 1910 düğümden oluşan ağın tamamının yerine görsel açından daha uygun görülen kesiti Şekil 6'te verilmiştir. İlk bakışta anlaşıldığ üzere araştırılan kavramlar sadece lojistik ile alakalı olmaktan çıkıp işletmenin tamamına nüfus etmeye başlamıştır.

İlgili döneme ait istatistiki bulgular aşağıda Tablo 6’te yer almaktadır.

Tablo 6: 2015-2018 Yı1ları Arası Anahtar Kelimelerin Ağına İlișkin Merkezilik Ölçütleri

\begin{tabular}{lcllll}
\hline Etiket & Derece & Yakınlık Merkeziliği & Arasındalık Merkezilï̆i & Eigen Merkeziliği \\
\hline Lojistik & 173 & 0.4745417515274949 & 0.20539298679750365 & 1.0 \\
\hline Sürdürülebilirlik & 24 & 0.40486533449174633 & 0.023971527863666423 & 0.19280137988201745 \\
\hline Tedarik Zinciri & 24 & 0.39225589225589225 & 0.015736984427263078 & 0.21142392031514418 \\
\hline Türkiye & 22 & 0.37886178861788616 & 0.020124671958286003 & 0.16308280082759835 \\
\hline Diş Ticaret & 21 & 0.3810302534750613 & 0.010412981172498807 & 0.20318080747597253 \\
\hline Tersine Lojistik & 21 & 0.30006439150032194 & 0.023654765328622103 & 0.04489213138379026 \\
\hline Lojistik Merkez & 19 & 0.3669291338582677 & 0.009961472670710486 & 0.16345255466930356 \\
\hline Müssteri Memnuniyeti & 18 & 0.35383447228549736 & 0.0076957237216978384 & 0.1479352783774536 \\
\hline AHP & 18 & 0.31422791638570463 & 0.017605224823886233 & 0.07691132821852543 \\
\hline İşletme Performans1 & 16 & 0.33768115942028987 & 0.01541693776105537 & 0.11865525984805171 \\
\hline Pazarlama & 11 & 0.3314366998577525 & 0.0027447489397446254 & 0.10543982384405035 \\
\hline Tesis Yeri Secimi & 10 & 0.2720373613543491 & 0.005061834915156744 & 0.051342293702700964 \\
\hline E-Ticaret & 10 & 0.330028328611898 & 0.00787335339288994 & 0.1269186464895561 \\
\hline Performans Ölçümü & 10 & 0.36152055857253684 & 0.0034784559685790218 & 0.11104766293293054 \\
\hline Yeşil Tedarik Zinciri & 10 & 0.3261021693491952 & 0.0022275502984393405 & 0.08986580262095434 \\
\hline
\end{tabular}

Derece sıralamasına göre verilen Tablo 4'te yer almayan üretim ve maliyet yönetimi ifadeleri arasındalık merkeziliği bakımından önem taşımaktadırlar. Bu da göstermektedir ki disiplinler arası faaliyetlerin incelenmesi lisansüstü tezler bakımından artan bir öneme sahiptir. Bu dönemde sürdürülebilirlik, müşteri memnuniyeti ve e-ticaret kavramlarının lojistik ile beraber kullanılmakta olduğu görülmektedir. Makalede Times New Roman yazı fontu kullanılmalıdır. Ancak bazı alanların gereği olarak yazım esnasında özel font kullanılmış ise bu fontlar makale ile birlikte sisteme yüklenmelidir.

\section{Sonuç ve Tartışma}

1990-2018 yılları arasında Lojistik alanında yayımlanmış lisansüstü tez çalışmalarının anahtar kelimelerinin sosyal ağ analizi yöntemiyle incelenmesi sonucunda alanda en önemli kavramlar; tedarik zinciri yönetimi, dış kaynak kullanımı, lojistik merkez ve tersine lojistiktir. Bu kavramlar tezlerin literatürde yer almaya başlamasından günümüze değin önemlerini korumuşlardır.

Ancak zamana dayalı olarak yaşanan değişimin gözlemlenebilmesi için yapılan dinamik analizde açıkça görülmektedir ki incelenen kavramlar lojistik biriminden işletmenin tamamına, incelenen bölgeler ise firma ve şehirlerden ülkenin bütününe doğru bir paradigma değişimini yansıtacak biçimde evrilmektedir. Elbette bunun altında yatan nedenler olarak birçok unsur sıralanabilir. Öncelikle holistik bakış açısının getirdiği, sorunsalı bütün içerisinde görme ihtiyacı buna sebep olabilir. Ayrıca bir alanda gelişim sağlandıkça temel sorunsalların sağlam temellere dayandırılmaları ve daha farklı konulara eğilme fırsatının araştırmacılar tarafından fark edilmesi de bir diğer neden olabilir.

Türkiye'de Lojistik literatürü henüz çok eski bir geçmişe sahip olmamakla birlikte gelişim açısından oldukça yüksek bir ivmeye sahiptir. Bu çalışmanın temel amacı olarak öne sürülen Lojistik alanının gelişiminin resmedildiği bu çalışmanın ortaya koyduğu üzere disiplinler arası çalışmalar giderek önem kazanmaktadır. Ayrıca bölge ve ülke kavramlarının yeterince irdelenmesinden sonra küresel kapsamda çalışmaların daha sıklıkla yapılması da ilerleyen dönemlerde olası bir durumdur. 
Araştırma sonuçlarına göre tedarik zinciri yönetimi, lojistik yönetimi, tersine lojistik gibi lojistiğin temel alanlarında her dönemde çalışmalar yapıldığı görülmektedir. 2015-2018 dönemimde ilk defa yeşil tedarik zinciri yönetimi ile ilgili çalışmalar yapılmaya başlandığı tespit edilmiştir. Lisansüstü tez çalışmaları bakımından inovatif lojistik ya da lojistik yenilikçiliği, yeşil lojistik, şehir lojistiği, insani yardım lojistiği, afet lojistiği, lojistik bilgi teknolojileri, lojistik esnekliği, çevikliği ve entegrasyonu gibi alanlarda çalışmalara yeterli önemin verilmemiş olduğu görülmektedir. $\mathrm{Bu}$ nedenle araştırmacıların lojistikteki güncel yaklaşımlar olarak değerlendirilen bu alanlarda da çalışmalar yapması lojistik literatürüne katkı sağlamak bakımından önemli olacaktır. Çünkü lojistik tedarik zinciri ağında, tedarikçinin tedarikçisinden müşterinin müşterisine kadar uzanan zincirde her aşamada önemli rol oynamaktadır. Rekabet edebilirlik için, sürdürülebilirlik için lojistiğin etkin yönetimi, lojistiği tek başına değil diğer bütün disiplinler ile ilişki içerisinde düşünmek son derece önemlidir.

$\mathrm{Bu}$ araştırmanın kısıtlarının başında incelenen veri setinin lisansüstü tezlerden oluşması gelmektedir. Makale, bildiri, vb. çalışmalar araştırmada yer almamıştır. Ancak bir alanda yayımlanan lisansüstü tezler ilgili alanda mevcut durumda bulunulan noktayı temsil etmeleri bakımından büyük önem taşımaktadırlar. Bundan dolayı incelenmeleri oldukça büyük önem taşımaktadır. Bazı tezlerin yayınlanma izinlerinin veya anahtar kelimelerinin olmaması derlenen çalışmaların sayısında azalmaya neden olmuş ve analiz tarihi 1997 yılından başlayabilmiştir. Bir diğer kısıt olarak analiz ortamında elde edilen verilerin tamamının yayın ortamında yansıtılamamış olması sayılabilir. En düşüğü 577 satırdan başlayan ağ haritalarına ilişkin istatistiki bulguların, fiziksel sınırlar nedeniyle tamamı verilememiştir. Bunun yerine en önemli ilk 15 düğümün verilmesiyle yetinilmiştir. Yine aynı nedenle ağ haritalarının görsellerinin tamamı yerine sadece önemli düğümlerin yer aldığı kesitler verilmiştir.

\section{Kaynakça}

Acar, A. Z., ve Gürol. (2013). Türkiye'de Lojistik Yazınının Tarihsel Gelişimi. İşletme Araştırmaları Dergisi, 5(3), 289-312.

Ağcasulu, H. (2018). Sosyal Bilimlerde İlişkileri İnceleyen bir Yöntem: Sosyal A ̆g Analizi. Atatürk Üniversitesi Sosyal Bilimler Enstitüsü Dergisi, 1915-1933.

Al, U., Sezen, U., ve Soydal, İ. (2012). Hacettepe Üniversitesi Bilimsel Yayınlarının Sosyal A $\breve{g}$ Analizi Yöntemiyle Değerlendirilmesi. Hacettepe Üniversitesi Edebiyat Fakültesi Dergisi, 29(1), 53-70.

Álvarez, H. R., ve Serrato, M. (18-22 Mayis 2013). Social Network Analysis for Humanitarian Logistics Operations in Latin America. Industrial and Systems Engineering Research Conference, (s. 3835-384). Puerto Rico.

Aslan, H., Taşçı, H., ve Yıldız, B. (2018). The Effect of Logistic Service Quality and Logistic Information Technology on Logistics and Firm Performance. Journal of Current Researches on Social Sciences, 8(1), 343-358.

Ataman, F., ve Çelik, E. (2018). Entelektüel Yapıların Sosyal A ̆ Analizi İle Görselleştirilmesi: Van Yüzüncü Yil Üniversitesi Üzerinde Bibliyometrik Bir Analiz. Yüzüncü Yıl Üniversitesi Fen Bilimleri Enstitüsü Dergisi, 23(1), 34-47.

Borgatt1, S. P., ve Li, X. (2009). On Social Network Analysis in a Supply Chain Context. Journal of Supply Chain Management, 45(2), 5-22.

Borgatti, S. P., Everett, M. G., ve Johnson, J. C. (2013). Analyzing Social Networks. SAGE. 
Burt, R. S. (2005). Brokerage and Closure: An Introduction to Social Capital. Oxford University Press.

Codal, K. S., ve Coşkun, E. (2016). Sosyal Ağ Türlerinin Karşılaştırılmasına İlişkin Bir Ağ Analizi. AIB̈Ü Sosyal Bilimler Enstitüsü Dergisi, 16(1), 143-158.

Crane, D. (1972). Invisible Colleges; Diffusion of Knowledge in Scientific Communities. Chicago: University of Chicago Press.

Demirgil, H., ve Çelikkaya, S. (2019). Bölgesel Kalkınma Çalışmalarında Ortak Yazarlık ve Atıf Ağlarının Sosyal Ağ Analizi ile İncelenmesi. Yönetim ve Ekonomi Araştırmaları Dergisi, 17(4), 296-315.

Freeman, L. C. (1978). Centrality in Social Networks Conceptual Clarification. Social Networks, 1, 215-239.

Heinze, T., ve Kuhlmann, S. (2008). Across İnstitutional Boundaries?: Research Collaboration in German Public Sector Nanoscience. Research Policy, 37(5), 888-899.

Karagöz, D., ve Kozak, N. (2014). Anatolia Turizm Araştırmaları Dergisi'nin Bibliyometrik Analizi: Araştırma Konuları ve Kurumlar Arası İş Birliğinin Sosyal Ağ Analizi ile İncelenmesi. Türk Kütüphaneciliği, 28(1), 47-61.

Karagöz, D., ve Yüncü, H. R. (2013). Sosyal Ă̆ Analizi ile Turizm Alanında Yazılmış Doktora Tezlerinin Araştırma Konularının İncelenmesi. , (15) ,. Adlyaman Üniversitesi Sosyal Bilimler Enstitüsü Dergisi, 15, 205-232.

Kervankıran, İ., Eteman, F. S., ve Şardağ, A. (2019). Türkiye'de Turizm Coğrafyası Araştırmalarında Disipliner İlişkinin Sosyal A $\breve{g}$ Analizi ile İncelenmesi. Gaziantep Üniversitesi Sosyal Bilimler Dergisi, 18(3), 938-965.

Kim, Y., Choi, T. Y., Yan, T., ve Dooley, K. (2011). Structural Investigation of Supply Networks: a Social Network Analysis Approach. Journal of Operations Management, 29, 194-211.

Lambiotte, R., ve Panzarasa, P. (2009). Communities, Knowledge Creation, and Information Diffusion. Journal of Informetrics, 3(3), 180-190.

Lin, N., Fu, Y., ve Hsung, R. (2001). The Position Generator: Measurement Techniques for Investigations of Social Capital . N. Lin, K. Cook, ve R. Burt içinde, Social Capital: Theory and Research (s. 57-81). Walter de Gruyter.

Moody, J. (2004). The Structure of a Social Science Collaboration Network: Disciplinary Cohesion From 1963 to 1999. American Sociological Review, 69(2), 213-238.

Phillips, D. M., ve Phillips, J. K. (1998). A Social Network Analysis of Business Logistics and Transportation. International Journal of Physical Distribution ve Logistics Management, 28(5), 328-348.

Sonnenwald, D. H. (2007). Scientific Collaboration. Annual Review of Information Science and Technology, 4l(1), 643-681.

Storer, N. W. (1966). The Social System of Science . Holt, Rinehart and Winston.

Suvacı, B. (2016). Sosyal Bilimler Veri Tabanında Yayımlanan Lojistik ve Tedarik Zinciri Makalelerinin Bibliyometrik Profili. Süleyman Demirel Üniversitesi Sosyal Bilimler Enstitüsü Dergisi , 3(25), 263-281. 
Tekdal, M., Baz, F. Ç., ve Saygıner, Ş. (2017). Sosyal Ağ Analizi Yazılımları Üzerine Karşıllaştırmalı Bir İnceleme. Uluslararası Bilgisayar ve Ögretim Teknolojileri Sempozyumu, 26-26 Mayıs, (262-268).

Tunçay, S. S., ve Özer, P. S. (2017). Asil-Vekil İlişkilerinin Kültürel Bağlamda Sosyal Ağ Kuramı Çerçevesinde Sosyal A $\breve{g}$ Analizi Kullanılarak İncelenmesi. İşletme Araştırmaları Dergisi, 9(2), 478-510.

Tunçay, S. S., Özer, P. S., ve Tozkoparan, G. (2015). Yerel Yazında Sosyal Sermaye Araştırmalarn: Odaklar ve Boşlukların Sosyal Ağ Analizi İle İncelenmesi. Dokuz Eylül Üniversitesi Işsletme Fakültesi Dergisi, 16(2), 71-89.

Wichmann, B. K., ve Kaufmann, L. (2016). Social Network Analysis in Supply Chain Management. Research International Journal of Physical Distribution ve Logistics Management, 46(8), 740-762. 